\title{
THE STUDY OF CRITERION-LEVEL APPROACH TO THE FORMATION OF ECONOMIC COMPETENCES IN SENIOR PUPILS
}

\author{
Iryna Klymchuk \\ Institute of Pedagogy of the National Academy of Pedagogical Sciences of Ukraine \\ 52-D Artema str., Kyiv, Ukraine, 04053 \\ klimchuk.irina@gmail.com
}

\begin{abstract}
The effectiveness of any learning is formed on the base of analysis of mastered content of correspondent learning programs/ courses with gradually understood formation of the certain level of education/competences of individuals.

In the article is offered an analysis of assessment of establishing of correspondent levels of the learning achievements of senior pupils in the process of study of economic subjects. Author considers an algorithm of diagnostics of formation of economic notions in senior pupils from the point of view of personal-activity approach to the study of school courses on economics that is directly based on the own reflexive activity of pupils, personal interest in the further deepening of received knowledge.

The elaborated algorithm of diagnostics of formation of the market economy notions in senior people is presented in stages, namely: getting of the primary information, its elaboration and analysis; determination of conceptual bases of the levels of formation of the mains notions of market economy (ascertaining stage of research); elaboration of criteria of diagnostics of formation level of economic competences in senior pupils; determination of the final stage of formation of the market economy notions, analysis and assessment of the received results of research (forming stage of research) with taking into account of the certain level of reflection. There are given the results of expert assessment of the primary and final stages of the study of economic readiness of the senior pupils of general educational institutions of economic and non-economic type with taking into account of personal interest as to the further study of economy bases.
\end{abstract}

Keywords: effectiveness, competence, criteria and levels of assessment, algorithm of diagnostics of economic notions formation, reflexive activity of pupils.

\section{Introduction}

The category of diagnostics of formation of the market economy notions in senior pupils of the general educational institutions - is a complicated process of establishing of the certain level of mastering of the elements of knowledge base, revelation of the possible fluctuations and deviations in the system of formation of economic education of pupils and also elaboration of the assessment criteria of the formed levels.

Determination of the level of learning achievements of pupils is very important, because the learning activity finally must not only give the amount of knowledge, abilities and skills to human but also must form the certain level of its competence as the general ability that is based on knowledge, practical experience, personal abilities, formed by the study. The notion of competence cannot be reduced only to knowledge and skills but belongs to the sphere of formation of complicated abilities and certain personal qualities.

International educational community considers the competence approach as a main instrument of rise of education quality. Thus, in the report of UNESKO International commission on education for XXI century (1996) were formulated four principles that education must be based on: to learn to live together, to learn to gain knowledge, to learn to work, to learn to live rationally $[1,2]$.

European Council, carrying out international researches in education branch, deepening and adding the list of main competences, offers the following list of main competences that must be possessed by the young Europeans: social, connected with social activity of the person, with life of society; motivational, connected with interests, individual choice of person; functional, connected with the sphere of knowledge, ability to operate the acquired scientific knowledge and fact material.

The list of main competences, formed at studying at school, is determined by the aims of general secondary education of Ukraine and by the main directions of learning activity of comprehensive educational institutions that, in their turn, must favor the process of mastering of the cer- 
tain social experience, life skills and practical activity by pupils for their further use in professional carrier. Their specificity is conditioned by the frames of each learning subject.

The topicality of research is conditioned by the necessity of further elaboration of criteria and levels of measuring and assessment of the learning achievements of senior pupils in the process of studying natural subjects of economic type for formation of their competence and gaining certain practical skills with taking into account of the own reflexive activity of pupils.

\section{Analysis of literary data}

Competence as an integral result of pupils' learning activity is formed, first of all, on the base of mastering of the content of correspondent learning material. To reveal the level of such mastering is possible with the help of assessment, that is mechanism of establishing of the levels of learning achievements of pupils in mastering of the content of certain subject and also abilities and skills according to the requirements, accepted by MES of Ukraine.

The main normative acts formulate the following functions of assessment of the levels of learning achievements of pupils:

- control that provides determination of the level of achievements of separate pupil, revelation of the level of readiness to the mastering of new material that gives teacher a possibility to plan and give the learning material correspondingly;

- learning that conditions such organization of assessment of the learning achievements of pupils, when realization of assessment favors repetition, learning, specification and deepening of knowledge, systematization and improvement of skills and abilities;

- diagnostic-correction that provides elucidation of causes of problems that appear in pupil at the learning process, revelation of gaps in knowledge and abilities and introduction of adjustments, directed on elimination of these gaps, in activity of pupil and teacher;

- stimulation-motivation that determines such organization of assessment of the learning achievements of pupil that stimulates the desire to improve own results, develops responsibility, favors competitiveness, forms positive motives of learning;

- upbringing that is formation of ability to work responsibly and attentively, to use the techniques of control and self-control, it favors the development of diligence, activity and other positive personal qualities [3-6].

But according to many researchers [7-20] the dynamics of competence formation in senior pupils must be determined with taking into account of the certain criteria, namely: fundamentality and reflexivity of acquired knowledge that, in its turn, must provide:

- guaranteeing of integrity of perception of the "world picture", systemacy of knowledge;

- formation of understanding of specificity of the separate phenomena and processes;

- guaranteeing of "flexibility" of knowledge, ability to self-analysis, motivation to the further study or to the solution of different living problems.

It must be noted, that learning process on the mastering of economic courses by pupils, from the point of view of assessment of the levels of their achievements has criterion-level approach. In this research we proceed from the state standards, especially: "Criteria and levels of assessment of the learning achievements of pupils", accepted by MES of Ukraine [3-6]. That is why the aforesaid reference points were put in the base of assessment of the four levels of learning achievements of pupils as to their competence: primary, intermediate, sufficient, advanced.

Analyzing the scientific-methodical support of courses "Bases of economics", "Commercial geography" "Geography of the world economy with economics bases" and other, approved by MES of Ukraine, was made a conclusion that in the learning process senior pupils gain the following levels:

1. Level of formed necessary general economic knowledge, provided by the state standard of the general secondary education in program "Bases of economics", edited by I.F. Radionova; "Economics, 10 class" by G. O. Kovalchyuk, V. Y. Bobrov, V. G. Melnichyuk, O. O. Ogneviuk and other; "Bases of economics. 10-11 classes", edited by L. P. Krupska; "Bases of economics, 10-11 classes", edited by S. V. Stepaenko) [6, 17, 21-24];

2. Level of formed special economic knowledge, provided by the state and regional educational standards, which helps pupil in the further personal choice of the necessary profession 
("Bases of management", edited by G. O. Gorlenko, "Private business", edited by G. O. Gorlenko, "Bases of consumption knowledge") [25].

On the base of many studies was elaborated an algorithm of diagnostics of formation of the market economy notions that provided [7-11, 15, 16-20, 26-29]:

a) getting of the primary information, its elaboration and analysis;

b) determination of conceptual bases of the primary level of formation of the main notions of market economy (ascertaining stage of research);

c) elaboration of methodology of research, construction of the model;

d) experiment with use of the offered model (forming stage of experiment);

e) determination of the final level of formation of the market economy notions, analysis and assessment of the received results of research (control-correcting stage of research);

f) elaboration of methodological recommendations as to the further improvement of the process of formation of the main notions of market economy in senior pupils of general educational institutions.

At the research and assessment of results we faced the problem of assessment of acquired knowledge. Taking into account the studies of many scientists [2, 7-20, 24, 26, 28, 30] and own research, we made a conclusion that assessment of the level of formation of the main notions of market economy in senior pupils and also knowledge on bases of economy must be characterized by:

1) deepness and comprehensiveness;

2) distinctness and completeness of mastered notions;

3) scientific reliability;

4) level of reflexivity;

5) possibility of the further practical use.

\section{Aim and task of research}

The aim of research was elaboration of an algorithm of diagnostics of formation of the market economy notions in senior pupils. It provided such stage/tasks:

1) getting of the primary information, its elaboration and analysis;

2) determination of conceptual bases of the levels of formation of the mains notions of market economy (ascertaining stage of research);

3) elaboration of criteria of diagnostics of formation level of economic competences in senior pupils;

4) determination of the final stage of formation of the market economy notions, analysis and assessment of the received results of research (forming stage of research) with taking into account of the certain level of reflection.

\section{Materials and methods of research}

For solving the set tasks we used the following methods of research: theoretical - analysis and comparison of results of scientific study on psychology, pedagogy and methodology of teaching: analysis and systematization, generalization of conceptions, methodologies, programs with which help were revealed the ways of solution of the problem of research and determined criteria and levels of the notions formation; modeling of the learning process with which help was elaborated the theoretical-applied model of formation of the main notions of market economy in senior pupils and also technology and mechanism of its realization in conditions of general educational institution; empirical - questioning, testing, conversation, observation with which help was studied the state of formation of the market economy notions in senior pupils of GEI; method of pedagogic experiment (ascertaining, forming, summing) - for check of the effectiveness of elaborated model; methods of processing of experimental data, especially the one of statistic survey for getting data (ranging, rating) and analytic method as a method of establishing of analytic (functional) dependence between conditions (factors) of formulated problem and received results that gave a possibility to assess the final result of formation of economic notions. 


\section{Results of research}

The effectiveness of study is formed, first of all, on the base of analysis of the mastered content of correspondent courses of the natural direction with gradual formation of the certain level of education/competence of individuals with the help of assessment - process of establishing of correspondent level of the learning achievements of pupil in mastering of the content of certain subject, abilities and skills according to the requirements of learning programs/standards [11, 12, 29].

Let's note that the "object of assessment" of learning achievements of pupils is not only the set of knowledge, abilities and skills but also experience of personal-axiological attitude to the surrounding reality.

It must be noted, that the learning process on mastering of courses: "Bases of economics", "Commercial geography", "Geography of the world economy with economic bases" by pupils, from the point of view of assessment of the levels of their achievements has criterion-level approach. In this research we proceed from the state standards, especially: "Criteria and levels of assessment of the learning achievements of pupils", accepted by MES of Ukraine [3-6]. That is why the aforesaid functions of assessment were put in base of assessment of the four levels of learning achievements of pupils: primary, intermediate, sufficient, advanced.

According to the competences of economic education were assessed theoretical knowledge of pupils on the bases of economic theory and gaining abilities and skills to use the acquired knowledge in everyday life, namely, at analysis of concrete living situations with the further optimal choice of solution of practical tasks, connected with economic activity of human, family, society, state; analysis of economic phenomena, events, situations that takes place in society formation in youth of the strong motivations to the further deepening of economic education and economic literacy.

At research and summing up results we determined the levels of learning achievements of pupils according to the following criteria, approved by the state normative acts:

- Primary level - criterion of assessment - pupil realizes cognitive activity only under the guidance of teacher; reproduction of the learning material is fragmental. The result of study of learning material is cognition by pupil of economic phenomena, categories, notions and one-word answer to the question. At this level pupil is not yet able to solve problems, build and read graphs of economic content, describe from economic point of view his/her own choice or actions.

- Intermediate level - criterion of assessment - pupil with the help of teacher reproduces information, mastered at studying the course "Bases of economics" (knowledge and abilities are copies); he tries to compare the demonstrated or earlier described economic phenomena with their characteristics, formulas, graphs and so on, that is to establish certain connections without explanation of causes; pupil tries to use the separate techniques of logical thinking (comparison, analysis, conclusion); tries to solve economic exercises with one operation, which general methodology, successiveness and formulas of calculations are familiar to him/her; tries to use acquired knowledge for explanation of own decisions or actions.

- Sufficient level - criterion of assessment - pupil realizes cognitive activity independently, sometimes asks for teacher's consultation. He/she understands and consciously reproduces the learning material, uses in typical situations the techniques of logical thinking (comparison, analysis, conclusion); independently solves typical economic exercises; can use acquired knowledge on bases of economics in typical situations, independently prove own statement but with some possible inaccuracies; can use additional sources (except textbook and teacher's lectures); can observe the economic announces in mass media and make some conclusions.

- Advanced level - criteria of assessment - pupil freely possesses the content of topic and deeply understands the main economic notions, laws and categories; illustrates knowledge with own examples; can reproduce the whole mastered topic or its certain part, indicating causes, interconnections, consequences, grounding own points of view; solves economic exercises, which methodology and succession (algorithm) are familiar but which content includes several topics (combined exercises); solves new exercises; makes plan of solution of the new task, offers original methods of solution, grounds results, introduces in own activity certain elements of creativity; pupil competently and creatively uses the material of press, TV, normative documents; expresses own position as to economic processes that take place in society. 
Assessment of the levels of learning achievements of pupils consisted of assessment of theoretical knowledge (control works) and also of the level of its practical use (role and business economic games).

At that the types of assessment of learning achievements of pupils in this research were: current, thematic, semester, annual assessment (state concluding control work).

Current assessment was realized in the process of study of the topic by lessons. Its main tasks are establishing and assessment of the levels of understanding and primary mastering of the separate elements of content of the topic, establishing of connections between them and mastered content of previous topics, fixation of knowledge, abilities and skills.

The forms of current assessment were: individual questioning; work with diagrams, graphs, schemes; drawing of geographic objects; work with contour maps; carrying out of the different types of written works by pupils; mutual control of pupils in pairs or groups; self-control and so on. In conditions of introduction of experiment the testing form of control gained the special importance.

Information, gained at current control, was the base of correction of teachers' work on the lessons of economics and geography.

Thematic assessment of the learning achievements included the main results of study of the separate topic (section). Thematic assessment of the learning achievements of pupils during experiment favored elimination of the following defects:

- elimination of the lack of system in assessment;

- rise of objectivity in assessment of knowledge, abilities and skills;

- individual and differential approaches to organization of the study;

- systematization and generalization of learning material;

- concentration of pupils' attention on the most essential in system of knowledge of each subject.

Thematic assessment took place on the base of results of mastering by pupils of the topic material during its study, taking into account the current marks, different types of learning works (practical, laboratory, control ones) and learning activity of schoolchildren.

Before the start of learning of the next topic all pupils were acquainted with duration of its study (number of lessons); number and subject of obligatory works and terms of their realization; conditions of assessment. In the process of study of the topics of significant volume was allowed carry out several intermediate thematic assessments. And on the contrary, if the mastering of topic provides, for example, 2-3 academic hours they must be combined for the thematic assessment. The mark for semester was put according to the results of thematic assessment and for year, correspondingly, - on the base of semester marks.

Diagnostics of the primary and concluding levels of formation of market economy notions in senior pupils of the general educational institution was realized in the process of ascertaining stage and at the different phases of forming stage of research.

At ascertaining stage of research the following parameters were given as preliminary (intermediate) criteria of assessment of the level of economic knowledge in senior pupils:

- ability to recognize the main economic notions; to elucidate the main signs of economic notions, categories, laws;

- ability to give definition of the main economic notions, laws, categories; to compare them, to explicate their essence and meaning;

- ability to argue, to defend own opinion about one or another economic phenomena; to analyze living situations, using certain economic notions, categories, laws;

- degree of pupils' personal motivation to the further deepening of knowledge on the bases of market economy.

At the forming stage the following parameters were taken as final (concluding) criteria of assessment of the level of economic knowledge in pupils:

- ability to solve problems on atypical situation, using knowledge of economic notions, categories and laws, to analyze, to determine certain regularities;

- possibility to offer own ideas as to development of situation, events, conflicts; to prove them; to offer own way out of nonstandard situation;

- degree of pupils' personal motivation to the further deepening of knowledge of the market economy functioning. 
At the forming stage were also taken into account such criterion as a personal ability to self-analysis that is elements of reflection and also its synthesis (combination) with acquired knowledge on the market economy bases and, thus, formation of the stable motivation to the further deepening of knowledge on bases of the market economy functioning.

It must be noted, that from the point of view of personal-activity approach to the study of certain discipline, the courses of economy were considered not as reproduction of certain set of information on the different economic subjects but as formed ability to own reflexive activity, directed on self-cognition through the cognition of subjects and phenomena of economic development.

For assessment of the levels of mastered material the following criteria of formation of self-assessment/reflection were used [2, 14, 17, 18, 26].

Low level of reflection formation is characterized with: absence of interconnection in operations with understood subjects and real phenomena; mastering of reflection of professional economic knowledge is casual, the system comprehension of the subject of economic analysis is absent.

Sufficient level of formation is characterized with following signs:

a) system comprehension of economic categories is complicated by absence of the distinct understanding of direct and reverse intersystem connections;

b) determination of elements of economic laws and categories is given at the level of facts, their interconnections are not concretized.

High level of reflection effectiveness is characterized with ordering of reflexive acts, their rationality and succession. At that the subject of reflection is considered in system interconnections, the structural system-creating elements are separated in the integral content of subject.

For sufficient and high levels of development of abilities to reflexive analysis in the sphere of economic education are typical the elements of foresight (prognostication) of the results of certain activity, based on the deep understanding of the essence of economic laws and categories: elaboration of diagnostically formulated aims of reflection formation; choice of most optimal methods of reflection management; creation of the normal relations between teacher and pupil.

From the personal-activity point of view economic education is considered not only as reproduction of certain set of information on the different subjects but as a formed ability to study, cognizing ourselves and "everything that surrounds us". According to the personal-activity approach, mastering of the content of historical experience is realized not by the way of transmitting information about its development to each person, but in the process of own reflexive activity, directed on self-cognition through cognition of the subjects and phenomena of economic development as the results of progressive development of any society. Below are given the results of expert assessment of the primary and final stages of the study of economic preparation of senior pupils of the general educational institutions of economic and non-economic type, taking into account the personal interest as to the further study of economics (Table 1).

Table 1

Number of pupils, taking into account of the personal interest as to the further study of economics (in \% of the general number of interrogated)

\begin{tabular}{cccccc}
\hline № & Levels & $\begin{array}{c}\text { Ascertaining stage } \\
\text { (pupils of specializes classes) }\end{array}$ & $\begin{array}{c}\text { Forming stage } \\
\text { Ascertaining stage }\end{array}$ & $\begin{array}{c}\text { Forming stage } \\
\text { (pupils of non-specialized classes) }\end{array}$ \\
\hline 1 & High & 9,9 & 27,4 & 4,8 & 15,8 \\
2 & Intermediate & 28,4 & 44,6 & 19,2 & 44,4 \\
3 & Low & 61,7 & 28,0 & 76,0 & 39,8
\end{tabular}

From the given data can be seen, that the level of pupils' self-assessment as to practical realization of the received economic knowledge is rather low at the primary stage comparing with the final stage of research. It persuasively testifies that pupils assess their economic preparation for the further independent activity rather low. 
As the further research shown it, for the sufficient and high levels of development of abilities to reflexive analysis in the sphere of economic education are typical the elements of foresight (prognostication) of the results of certain activity that, in its turn, must be based on the deep understanding of the essence of economic laws and categories and provides: elaboration of diagnostically formulated aims of reflection formation; choice of most optimal methods of teens' reflection management; creation of the normal relations between teacher and pupil.

\section{Conclusions}

1. In the process of collection and elaboration of primary information were formulated the main competences as to economic education at the level of general economic institution at the modern stage:

1) acquaintance with the bases of economic theory and applied economic disciplines (bases of business, entrepreneurial activity, accounting, management, marketing and so on);

2) formation of economic thinking in pupils;

3) formation in pupils of skills and abilities to make grounded decisions;

4) social adaptation of youth to changes in the modern society, connected with tendencies of the world economic development;

5) pre-professional orientation in the field of economic, legal, entrepreneurial activity and development of entrepreneurial abilities in pupils.

2. At determination of conceptual bases and levels of formation of the main notions of market economy in senior pupils (ascertaining stage of research) it is necessary to take into account the following parameters:

- characteristics of pupils' answers - completeness, integrity, logics, reasonableness, correctness;

- quality of knowledge - meaningfulness, deepness, flexibility, effectiveness, systemacy, generalization;

- degree of formation of the general learning and subject abilities and skills;

- level of possession of rational operations: ability to analyze, synthesize, compare, abstract, classify, generalize, make own conclusions and so on;

- experience of creative activity (ability to reveal problems and to solve them, to formulate hypotheses);

- independence of assessment judgments.

Assessment of the levels of formation of the main economic notions in pupils can be carried out according to four levels: primary, intermediate, sufficient and advanced:

- primary level - criterion of assessment - pupil realizes cognitive activity only under the guidance of teacher; reproduction of the learning material is fragmental. The result of study of learning material is cognition by pupil of economic phenomena, categories, notions and one-word answer to the question. At this level pupil is not yet able to solve problems, build and read graphs of economic content, describe from economic point of view his/her own choice or actions;

- intermediate level - criterion of assessment - pupil with the help of teacher reproduces information, mastered at studying the course "Bases of economics" (knowledge and abilities are copies); he tries to compare the demonstrated or earlier described economic phenomena with their characteristics, formulas, graphs and so on, that is to establish certain connections without explanation of causes; pupil tries to use the separate techniques of logical thinking (comparison, analysis, conclusion); tries to solve economic exercises with one operation, which general methodology, successiveness and formulas of calculations are familiar to $\mathrm{him} / \mathrm{her}$; tries to use acquired knowledge for explanation of own decisions or actions;

- sufficient level - criterion of assessment - pupil realizes cognitive activity independently, sometimes asks for teacher's consultation. He/she understands and consciously reproduces the learning material, uses in typical situations the techniques of logical thinking (comparison, analysis, conclusion); independently solves typical economic exercises; can use acquired knowledge on bases of economics in typical situations, independently prove own statement but with some possi- 
ble inaccuracies; can use additional sources (except textbook and teacher's lectures); can observe the economic announces in mass media and make some conclusions;

- advanced level - criteria of assessment - pupil freely possesses the content of topic and deeply understands the main economic notions, laws and categories; illustrates knowledge with own examples; can reproduce the whole mastered topic or its certain part, indicating causes, interconnections, consequences, grounding own points of view; solves economic exercises, which methodology and succession (algorithm) are familiar but which content includes several topics (combined exercises); solves new exercises; makes plan of solution of the new task, offers original methods of solution, grounds results, introduces in own activity certain elements of creativity; pupil competently and creatively uses the material of press, TV, normative documents; expresses own position as to economic processes that take place in society.

3. Assessment of criteria of mastering of economic knowledge with elements of certain level of reflection can be carried out with the help of following criteria:

1) personal motivation of senior pupils' needs for mastering of the system of modern economic knowledge on bases of the market economy;

2) personal system understanding of the problems of development of economic education in whole and of economics as a subject particularly;

3) primacy of individually personal needs and interests to the cognitive activity in economic sphere;

4) search for unconventional (innovative) ways of development of abilities and skills of system mastering of knowledge on bases of the market economy;

5) permanent deepening of information as to acquisition by the senior pupils of knowledge and abilities on development of the market economy (monitoring of the results of expert assessment of the level of economic education of senior pupils, rating assessment of gained knowledge and abilities).

4. Level of reflection of economic preparation of the senior pupils gave a possibility to change individually motivational settings of pupils from the primary personal dispassionateness and disinterestedness in the necessity of gaining the primary economic education to the strong motivation and personal activity in the sphere of deepening of economic education.

\section{References}

[1] Nacional'nyj doklad RF «Politika v oblasti obrazovanija i NIT» (1996). JuNESKO «Obrazovanie $\mathrm{i}$ informatika», INFO, $5,1-32$.

[2] Andersen, K., Bonni, T. M., Reyzer, M. L. (2005). Svitova heohrafiya z ekonomichnym ukhylom. Kuiv: Amadey, 221.

[3] Zakonodavstvo Ukrayiny pro osvitu (2002). Kyiv: Parlament, 159

[4] Hrazhevs'ka, N., Karpyuk, H., Klymyuk, I., Koval'chuk, H., Oliynyk, O. (2004). Zovnishnyetestuvannya z ekonomiky. Informaiyni materialy. Kyiv: Ukrainckainck rada z ekonom. osvity: Tsentr testovykh tekhnolohiy, 256.

[5] Beskova, N. V., Protsenko, V. M. (2005). Knyha vchytelya ekonomiky. Kharkiv: TORSINH PLYuS, 256.

[6] Osvita Ukrayiny: normativno-pravovi dokumenti (2001). Kuiv: Milenium, 472.

[7] Artashkin, T. A. (2007). Genezis i struktura celepolaganija v sisteme dejatel'nosti vysshej shkoly. Vladivostok, 22.

[8] Vasil'ev, Ju. K. (1990). Pedagogicheskoe upravlenie v shkole: metodologija, teorija, praktika. Moscow: Pedagogika, 139.

[9] Vas'kov, Yu. V. (2000). Pedahohichni teoriyi, tekhnolohiyi, dosvid. Kharkiv: Skorpion, 332.

[10] Pidkasystyy, P. I. (1972). Samostiyna diyal'nist' uchniv. Moscow: Pedahohika, 389.

[11] Pidlasyy, I. P. (1996). Pedahohika: pidruchnyk. Moscow: Pedahohika, 570.

[12] Savyts'ka, E. V. (1997). Uroky z ekonomiky. Moscow: Vita-Press, 315.

[13] Konarzhevskyy, Yu. A. (2000). Analyz uroka. Moscow: Tsentr „Ped. poysk”, 336.

[14] Klyns'kyy, P., Myunkh, O. (2007). Ekonomika dlya biznes litseyiv ta inshykh zahal'noosvtnikh shkil. Praha: FORTUNA, 386. 
[15] Orlov, A. A. (2000). Metodologicheskie osnovy obuchenija. Moscow: Marketing, 335.

[16] Podlasyj, I. P. (1996). Pedagogika. Moscow: Pedagogika, 570.

[17] Savickaja, E. V. (1997). Uroki po ekonomike. Moscow: Vita-Press, 315.

[18] Sirotenko, A. I. (1988). Ekonomicheskaja podgotovka uchashhihsja v processe obuchenija geografii. Kuiv: Radjans'ka shkola, 155.

[19] Shubin, N. L. (1997). Vnutrishkol'nyj kontrol'. Moscow: Prosveshhenie, 144.

[20] Jakovlev, E. V., Jakovleva, N. O. (2006). Pedagogicheskaja koncepcija: metodologicheskie aspekty postroenija. Moscow: MGU, 385 .

[21] Byeskova, N. (2005). Ekonomika 10 - 11 kl. Kyiv: Ped. presa, 80.

[22] Eds. Vatamanyuk, Z. H. Panchyshyna, Z. M. (1999). Ekonomika. Kuiv: Lybid', 383.

[23] Mel'nychuk, V. H., Koval'chuk, H. O., Ohnev»yuk, V. O. (2005). Ekonomika. Kuiv: Navch. knyha, 359

[24] Kyrylenko, L. M., Krups'ka, L. P., Parkhomenko, I. M., Tymchenko, I. Ye. (2004). Moya ekonomika: pidruchnyk dlya 8-9, 10 klasiv. Kuiv: A.P.N., 389.

[25] Horlenko, H. O. (2003). Zbirnyk zadach z ekonomiky. Kam»yanets'-Podil's'kyy: Abetka-Nova, 116.

[26] Klymchuk, I. O. (2003). Ekonomichna osvita v zahal'noderzhavniy shkoli: problemy i perspektyvy. Heohrafiya ta osnovy ekonomiky v shkoli, 6, 33-35.

[27] Kraevskyy, V. V. (1977). Sootnoshenye pedahohcheskoy nauky y pedahohycheskoy praktyky. Moscow: Polytyzdat, 272.

[28] Kuz'mina, N. V. (1970). Metody issledovanija pedagogicheskoj dejatel'nosti. Leningrad: Izd-vo Lenigrad, 125.

[29] Holubenko, M. (2006). Ekonomichna osvita shkolyara. Kuiv: Shkil Svit, 128.

[30] Pidkasistyj P. I. (1972). Samostojatel'naja dejatel'nost' uchashhihsja. Moscow: Pedagogika, 389. 